\title{
A new species of Australomedusa (Cnidaria: Hydrozoa: Anthomedusae) from a saline lake in south-western Western Australia
}

\author{
Wolfgang Zeidler ${ }^{1}$ and Lisa-ann Gershwin ${ }^{2}$ \\ ${ }^{1}$ South Australian Museum, North Terrace, Adelaide, South Australia, 5000, Australia \\ ${ }^{2}$ School of Marine Biology and Aquaculture, James Cook University of North Queensland, \\ Townsville, Queensland. 4811, Australia
}

\begin{abstract}
Australomedusa thrombolites sp. nov. is described from Lake Clifton, Yalgorup National Park. It is a small medusa with a bell height $(\mathrm{BH})$ of about $1.5 \mathrm{~mm}$. It differs from its only other congener, $A$. baylii, primarily in the shape and location of the gonads, and in having only 3-5 tentacles per cluster (verses 5-9). Furthermore, in preserved specimens, the tentacle length is relatively longer, about $75 \% \mathrm{BH}$, though this character tends to be highly variable in most medusa species.
\end{abstract}

\section{INTRODUCTION}

Very little is known of the non-marine medusan fauna of Australia. Despite extensive surveys of non-marine aquatic habitats by various researchers, medusae are rarely encountered. We suspect that this is partly due to the delicate nature of medusae, which often do not survive collecting techniques used for other taxa, but we also suspect that nonmarine medusae are genuinely rare in Australia.

Only two genera have thus far been recorded from Australian waters, the freshwater cosmopolitan genus, Craspedacusta, and the salt lake genus, Australomedusa. Craspedacusta tends to inhabit artificial lakes and ponds and has been recorded from all states except Tasmania and the Northern Territory. Australomedusa has only been recorded three times, firstly from south-eastern South Australia, just south of Robe (Russell 1970), secondly from the central coast of Victoria, near Inverloch (Russell 1971, Bayly 1973) and thirdly from a true estuarine system (the Werribee) west of Melbourne, Victoria (Neale and Bayly 1974). Only one species, A. baylii, is currently recognized.

In this paper we describe a new species, collected from Lake Clifton, a moderately saline lake in Yalgorup National Park, south-western Western Australia.

\section{MATERIALS AND METHODS}

Specimens were collected using a hand held 500 $\mu \mathrm{m}$ mesh plankton net from among, and over, thrombolites in about $1 \mathrm{~m}$ of water in Lake Clifton, Yalgorup National Park, Western Australia. They were relaxed with $\mathrm{MgCl}$ and preserved in $10 \%$ for maldehyde/propylene glycol solution.
Salinity was measured using an ICI 302 conductivity meter.

Sexes were determined as follows: gravid females were identified by the presence of spherical eggs or lumpy gonads. Mature males were identified on the basis of full gonads, which were smooth rather than lumpy. All specimens that could not be positively identified as mature males or gravid females were considered immature, though this category could conceivably include spawned specimens and probably also includes a disproportionate number of males.

The holotype male, allotype female and some paratypes have been deposited in the Western Australian Museum, Perth (WAM). Additional paratypes have been deposited in the South Australian Museum, Adelaide (SAM).

All of the material of $A$. baylii listed by Russell (1970, 1971), including the types, deposited in the Natural History Museum, London, was examined by one of us (L.G.) for comparative purposes.

\section{SYSTEMATICS}

Family Australomedusidae Russell, 1970

\section{Remarks}

When Russell (1970) described Australomedusa baylii he characterized the family thus, "in view of the multitentacular character of the marginal bulbs the erection of a new family, the Australomedusidae, would be justified with the diagnostic characters of the type genus Australomedusa." However, in his paper describing the females of $A$. baylii (Russell 1971) he reintroduced the family name as new only adding 
"the occurrence of only two types of nematocyst indicates that the medusa should be placed in a new family, Australomedusidae, fam. nov.". Clearly the correct citation for the family is Russell 1970; not 1971 as presumed by subsequent authors (e.g. Dumont 1994; Bouillon and Boero 2000).

\section{Genus Australomedusa Russell, 1970}

Australomedusa thrombolites sp. nov. Figure 1

\section{Material Examined}

\section{Holotype}

Male (WAM Z13498), Lake Clifton, Yalgorup National Park, south-western WA [32 $44.714^{\prime}$ 'S, $\left.115^{\circ} 39.230^{\prime} \mathrm{E}\right]$, collected at the thrombolite observation walkway, near 'Cape Bouvard' winery, by W. Zeidler and L. Gershwin, 10 December 2000.

\section{Allotype \\ Female (WAM Z13499), same collection data as holotype.}

\section{Paratypes}

11 males, 63 females, 31 juveniles, or specimens of undeterminable sex (SAM H1330); 10 males, 74 females, 31 juveniles, or specimens of undeterminable sex (WAM Z13500); same collection data as holotype.

\section{Diagnosis}

Australomedusa with 3-5 tentacles per group; with laterally flattened "gonads" in both sexes, approximately $1 / 3$, or less, the distance from the stomach to the margin.

\section{Description of holotype (male)}

Body spherical to globular, with a scattering of minute nematocyst warts on the whole exumbrellar surface. Stomach small, quadrate, tapering rapidly to short, narrow, cylindrical manubrium with simple mouth with four lips; attached directly to subumbrellar surface. Main gonads on interradial sides of manubrial wall; smoothly bulging. Lateral gonads small, roundish, flattened out laterally and barely protruding down into subumbrellar space; located on proximal $1 / 4$ or $1 / 3$ of radial canals. Tentacle bulbs four, perradial. Tentacles in clusters of three (only one bulb) or four; narrow and lacking nematocysts proximally, thickened somewhat and densely covered with nematocysts throughout distal $2 / 3$ to $3 / 4$; typically held outward in a fanlike fashion; about $3 / 4$ bell height $(\mathrm{BH})$ in length when preserved. Ocelli, one per tentacle cluster, located at the very distal center of the adaxial side. Radial canals, four, perradial, straight, smooth- edged, narrow. Ring canal same width as the radial canals. Each quadrant of bell margin typically with a single rudimentary interradial bulb or wart. Velum very wide. Statocysts not observed (lacking?). Color: In life, the body is transparent with a faintly greenish hue to the subumbrella; tentacles are faintly reddish in the outer half; the ocelli are bright red.

\section{Description of allotype (female)}

Like holotype, except that the gonads on the interradial walls of the manubrium appear lumpy with eggs. The lateral gonads do not appear to contain eggs. All tentacle bulbs with cluster of four tentacles.

\section{Variation from holotype and allotype}

Tentacle number: Variation in the number of tentacles on each marginal bulb is summarized for adult specimens in Table 1. Larger specimens tend to have more tentacles per cluster, but this is not constant; some smaller specimens have four-five, while some larger specimens only have three, and the number per cluster can vary in the same specimen, although it is most often four. Only one specimen had three tentacles on all four clusters and only three specimens had five tentacles on all four clusters. Similarly, the 62 juvenile specimens examined had 3-5 tentacles per cluster, seemingly unrelated to size, although details of tentacle distribution for individual specimens were not recorded.

Tentacle length: This varied from about $0.6 \mathrm{x}$ to $0.8 \times \mathrm{BH}$.

Table 1 Number of tentacles on marginal bulbs for adult specimens of Australomedusa thrombolites sp. nov. examined.

\begin{tabular}{lllll}
\hline $\begin{array}{l}\text { Number of } \\
\text { females }\end{array}$ & \multicolumn{4}{l}{$\begin{array}{l}\text { Number of tentacles on each } \\
\text { marginal bulb }\end{array}$} \\
\hline 113 & 4 & 4 & 4 & 4 \\
3 & 3 & 4 & 4 & 4 \\
4 & 3 & 3 & 4 & 4 \\
1 & 3 & 3 & 3 & 4 \\
1 & 3 & 3 & 3 & 3 \\
6 & 5 & 4 & 4 & 4 \\
2 & 5 & 5 & 4 & 4 \\
5 & 5 & 5 & 5 & 4 \\
3 & 5 & 5 & 5 & 5 \\
& & & & \\
Number of & & & & \\
13 & & & & 4 \\
4 & 4 & 4 & 4 & 4 \\
1 & 3 & 4 & 4 & 4 \\
1 & 3 & 3 & 4 & 4 \\
2 & 3 & 3 & 3 & 4 \\
1 & 5 & 4 & 4 & 4 \\
\hline
\end{tabular}




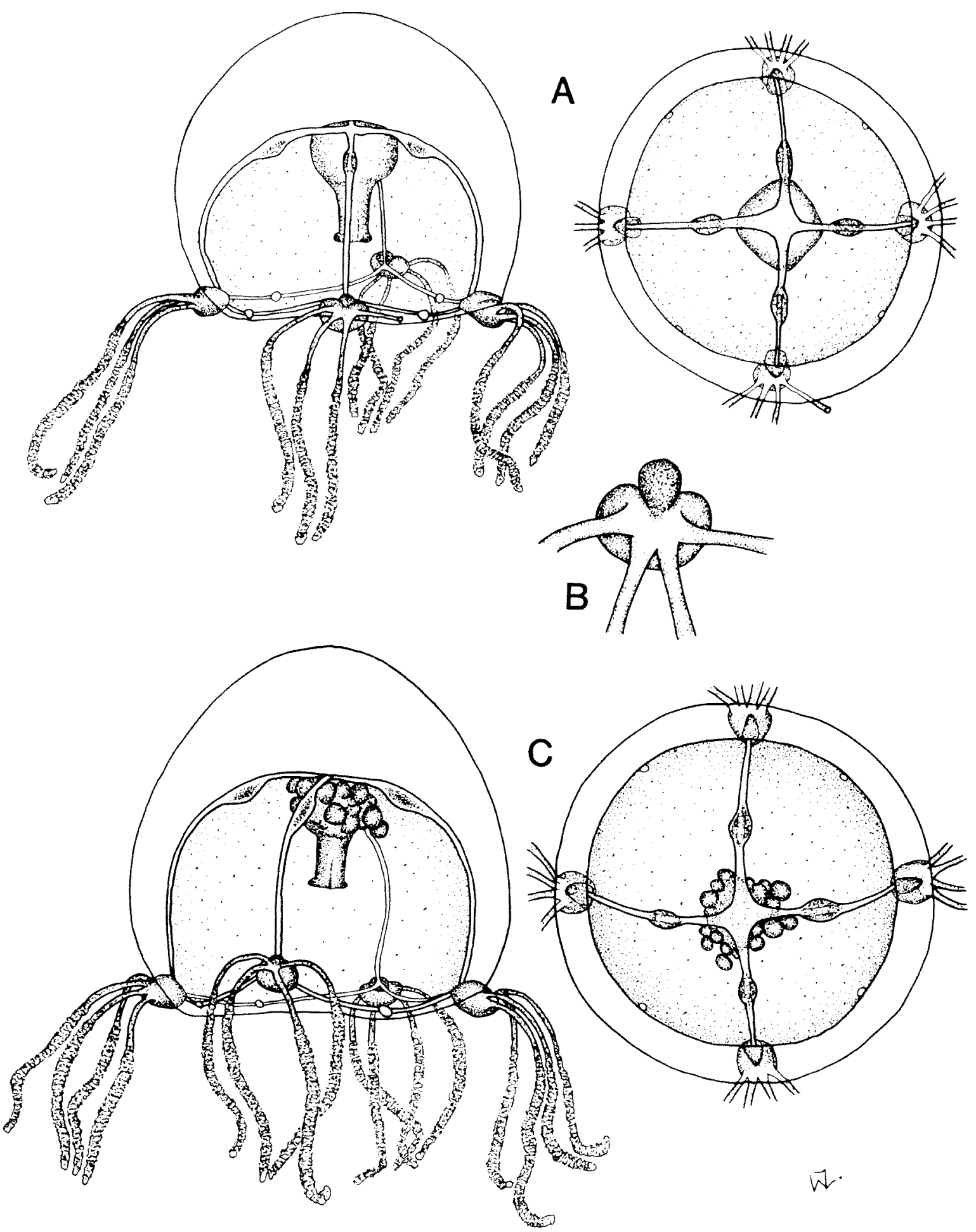

Figure 1 Australomedusa thrombolites sp. nov. A. Holotype male, lateral and aboral view. B. Tentacular bulb of holotype. C. Allotype female, lateral and aboral view.

Tentacle thickness: Some specimens have slightly thickened tentacles, particularly those without lateral gonads.

Nematocysts: The proportion of tentacle covered by nematocysts is highly variable, ranging from about the distal $2 / 3$ to about the distal $7 / 8$ but can be almost totally covered in specimens with thickened tentacles.

Presence of lateral gonads: Of the 138 specimens determined as females and the 22 specimens determined as males, 35 females $(26 \%)$ and 9 males $(41 \%)$ were without lateral gonads.

Location of lateral gonads: Never located beyond proximal $1 / 3$ of radial canal but are sometimes very close to the apex in some specimens.

Interradial marginal warts: Most specimens have only one wart per interradius. Some have two, or occasionally three, but never in all of the interradii. 
Only one specimen had four, but only in one interradius.

\section{Type locality}

Lake Clifton, Yalgorup National Park, southwestern WA $\left[32^{\circ} 44.714^{\prime} \mathrm{S}, 115^{\circ} 39.23^{\prime} \mathrm{E}\right]$. Salinity at time of collection $=31.5$ ppt .

\section{Distribution}

Only known from the type locality.

\section{Etymology}

The specific name "thrombolites" (pronounced "throm-bo-LITE-eez") is in reference to the dominant life form in the lake, the Lake Clifton Thrombolites.

\section{Remarks}

This species is similar to A. baylii Russell, 1970, but differs in several key characters. First, while the females of $A$. thrombolites have eggs clustered on the manubrium as do the females of $A$. baylii, the former possesses lateral gonads in both sexes, whereas they are lacking in the females of $A$. baylii. Second, the lateral "gonads" are of a different shape and location, being flattened laterally against the subumbrella, and located about $1 / 3$ the distance away from the stomach in $A$. thrombolites, whereas in $A$. baylii they start out adjacent to the stomach and move to the distal half of the radial canal, and they are pouched downward into the subumbrellar cavity. Third, the tentacle number in each cluster is only four (occasionally $3-5$ ) in A. thrombolites, but typically six-seven (occasionally $5-9$ ) in $A$. baylii. Tentacle number is independent of body size in both species, and is often unequal on the same specimen. Tentacle length in preserved specimens is about $75 \% \mathrm{BH}$ for $A$. thrombolites, compared to about $50 \% \mathrm{BH}$ or less for $A$. baylii. Russell (1971) mentions the occurrence of two types of nematocysts for $A$. baylii, desmonemes and microbasic euryteles. We lacked the facilities to examine the nematocysts of $A$. thrombolites in the field and obtained poor results with preserved material. Thus, comparison of this character will depend on the future examination of living material.

\section{DISCUSSION}

Two factors, which have become evident from the comparison of $A$. thrombolites with $A$. baylii, raise the question of whether the South Australian and Victorian populations of $A$. baylii are indeed the same species. First, the two populations of $A$. baylii from South Australia and Inverloch, Victoria are sexually dimorphic in gonad morphology, whereas A. thrombolites lacks sexual dimorphism and combines features of both sexes of $A$. baylii. Second, the South Australian and Victorian populations are geographically isolated from one another in inland salt lakes approximately $450 \mathrm{~km}$ apart, with suitable habitats in between, from which they are apparently absent. While studies of the more common freshwater genus Craspedacusta have demonstrated incredible dispersive capability, there are nonetheless several unique forms (see Jankowski 2001), as may be the case for Australomedusa.

On a recent field trip (7 Feb 2002) we visited the type locality of $A$. baylii (lake 12 of Bayly 1970) in order to collect fresh material, without success. The small lake known locally as "Lake Wylie" [37 $\left.16^{\circ} 48.2^{\prime \prime} \mathrm{S}, 139^{\circ} 49^{\prime} 59.1^{\prime \prime} \mathrm{E}\right]$ is located on the Karinya property just east of Lake Eliza, next to the Big Dip Conservation Park, about $17 \mathrm{kms}$ south of Robe. At the time of our study, the temperature was $22.5^{\circ} \mathrm{C}$, the salinity $25.5 \mathrm{ppt}$, and a green algal bloom was apparent. We also sampled two other lakes near the Karinya Homestead, an unnamed lake $\left[37^{\circ} 16^{\prime} 53.9^{\prime \prime} \mathrm{S}, 139^{\circ} 50^{\prime} \mathrm{E}\right]$ across the track from Lake Wylie, and one locally known as Lake Pudd [37 $\left.17^{\circ} 20.3^{\prime \prime} \mathrm{S}, 139^{\circ} 50^{\prime} 13.5^{\prime \prime} \mathrm{E}\right]$, about $1 \mathrm{~km}$ south-east of Lake Wylie. No medusae were found in either nearby lake, although both harbored diverse crustacean and molluscan faunas. The water of both lakes was clear, the temperature of both lakes was $22.5^{\circ} \mathrm{C}$, and the salinity was $32.0 \mathrm{ppt}$ and $29.5 \mathrm{ppt}$, respectively.

Thus, in the absence of fresh material, particularly of both sexes from the same locality, we are unable to resolve whether or not the known populations of A. baylii represent the same species.

\section{ACKNOWLEGEMENTS}

We thank Environment Australia (ABRS grant No. 20045) for funding the fieldwork and for providing funds for the second author to travel to Australia. We also thank the Western Australian Department of Conservation and Land Management for giving us permission to collect specimens from localities under their jurisdiction. Ms S. Halsey, Natural History Museum, London, is thanked for her hospitality and for providing the second author access to the collections. This research was completed while the senior author was an Honorary Researcher with the South Australian Museum and a Visiting Research Fellow in the Department of Environmental Biology, University of Adelaide.

\section{REFERENCES}

Bayly, I.A.E. (1970). Further studies on some saline lakes of south-east Australia. Australian Journal of Marine and Freshwater Research 20: 117-129. 
Bayly, I.A.E. (1973). Comments on medusae from inland waters and estuaries with reference to a recent find in Australia. Bulletin of the Australian Society for Limnology 4: 4-6.

Bouillon, J. and Boero, F. (2000). Synopsis of the families and genera of the Hydromedusae of the world, with a list of the worldwide species. Thalassia Salentina 24: 47-296.

Dumont, H. (1994). The distribution and ecology of the fresh- and brackish-water medusae of the world. Hydrobiologia 272: 1-12.

Jankowski, T. (2001). The freshwater medusae of the world - a taxonomic and systematic literature study with some remarks on other inland water jellyfish. Hydrobiologia 462: 91-113.
Neale, I.M. and Bayly, I.A.E. (1974). Studies on the ecology of the zooplankton of four estuaries in Victoria. Australian Journal of Marine and Freshwater Research 25(3): 337-350.

Russell, F.S. (1970). On a new species of medusa from an inland salt lake in South Australia. Journal of Zoology, London 162: 449-452.

Russell, F.S. (1971). On the female of the medusa Australomedusa baylii. Joumal of Zoology, London 164: 133-135.

Manuscript received 12 December 2002; accepted 16 January 2004 